Article

\title{
Time-Dependent Pathological Changes in Hypoperfusion-Induced Abdominal Aortic Aneurysm
}

\author{
Hirona Kugo ${ }^{1}$, Wanida Sukketsiri ${ }^{2}$, Hiroki Tanaka ${ }^{3}$, Rena Fujishima ${ }^{1}$, Tatsuya Moriyama ${ }^{1,4}$ (D) \\ and Nobuhiro Zaima ${ }^{1,4, *}$ \\ 1 Department of Applied Biological Chemistry, Graduate School of Agriculture, Kindai University, \\ 204-3327 Nakamachi, Nara 631-8505, Japan; hirona.kugo@gmail.com (H.K.); \\ rena21fujishima@gmail.com (R.F.); tmoriyama@nara.kindai.ac.jp (T.M.) \\ 2 Department of Pharmacology, Faculty of Science, Prince of Songkla University, Songkhla 90110, Thailand; \\ wanida.su@psu.ac.th \\ 3 Department of Medical Physiology, Hamamatsu University School of Medicine, Hamamatsu 431-3192, Japan; \\ 44htanaka@gmail.com \\ 4 Agricultural Technology and Innovation Research Institute, Kindai University, Nara 631-8505, Japan \\ * Correspondence: zaima@nara.kindai.ac.jp; Tel.: +81-742-43-7361
}

Citation: Kugo, H.; Sukketsiri, W.; Tanaka, H.; Fujishima, R.; Moriyama, T.; Zaima, N. Time-Dependent Pathological Changes in Hypoperfusion-Induced Abdominal Aortic Aneurysm. Biology 2021, 10, 149. https://doi.org/10.3390/ biology10020149

Academic Editor: Dario Brunetti

Received: 27 January 2021

Accepted: 12 February 2021

Published: 14 February 2021

Publisher's Note: MDPI stays neutral with regard to jurisdictional claims in published maps and institutional affiliations.

Copyright: (C) 2021 by the authors Licensee MDPI, Basel, Switzerland. This article is an open access article distributed under the terms and conditions of the Creative Commons Attribution (CC BY) license (https:/ / creativecommons.org/licenses/by/ $4.0 /)$.
Simple Summary: Abdominal aortic aneurysm (AAA) is a vascular disease that involves gradual dilation of the abdominal aorta and has a high mortality due to rupture. Hypoperfusion due to the obstruction of vasa vasorum, which is a blood supply system in the aortic wall, may be an important factor involved in AAA pathophysiology. A time-dependent analysis is important to understand the pathological cascade following hypoperfusion in the aortic wall. In our study, timedependent analysis using a hypoperfusion-induced animal model showed that the dynamics of many AAA-related factors might be associated with the increased hypoxia-inducible factor- $1 \alpha$ level. Hypoperfusion due to stenosis of the vasa vasorum might be a new drug target for AAA therapeutics.

Abstract: Hypoperfusion due to vasa vasorum stenosis can cause wall hypoxia and abdominal aortic aneurysm (AAA) development. Even though hypoperfusion is an important contributor toward pathological changes in AAA, the correlation between hypoperfusion and AAA is not fully understood. In this study, a time-dependent semi-quantitative pathological analysis of hypoperfusioninduced aortic wall changes was performed to understand the mechanisms underlying the gradual degradation of the aortic wall leading to AAA formation. AAA-related factors evaluated in this study were grouped according to the timing of dynamic change, and five groups were formed as follows: first group: angiotensin II type 1 receptor, endothelin-1 (ET-1), and malondialdehyde (MDA); second group: matrix metalloproteinase (MMP)-2, -9, -12, M1 macrophages (Mac387+ cells), and monocyte chemotactic protein-1; third group: synthetic smooth muscle cells (SMCs); fourth group: neutrophil elastase, contractile SMCs, and angiotensinogen; and the fifth group: M2 macrophages (CD163+ cells). Hypoxia-inducible factor- $1 \alpha$, ET-1, MDA, and MMP-9 were colocalized with alpha-smooth muscle actin cells in $3 \mathrm{~h}$, suggesting that hypoperfusion-induced hypoxia directly affects the activities of contractile SMCs in the initial stage of AAA. Time-dependent pathological analysis clarified the cascade of AAA-related factors. These findings provide clues for understanding complicated multistage pathologies in AAA.

Keywords: abdominal aortic aneurysm; hypoperfusion; vascular disease; hypoxia; inflammation

\section{Introduction}

Abdominal aortic aneurysm (AAA) is a vascular disease characterized by progressive dilation of the abdominal aorta. The risk factors for AAA include smoking, hypertension, male sex, and older age [1]. The risk of AAA rupture increases with an increase in AAA diameter [2]. The increased AAA diameter is caused by the continuous breakdown of the 
aortic wall structure, which is associated with several AAA-related factors [3]. The exact mechanisms underlying the breakdown of the aortic wall structure are not entirely clear.

The normal aortic wall consists of the intima, media, and adventitia. In the adventitia, small blood vessels called the vasa vasorum (VV) oxygenate the aortic wall [4]. Abnormal diffusion of oxygen to the aortic wall causes local hypoxia, which is associated with vascular remodeling $[5,6]$. In a previous study, we reported that VV stenosis causes hypoperfusion of the human abdominal aortic wall [7]. Similarly, induction of hypoperfusion in the aortic wall causes AAA formation and rupture in rats $[8,9]$, and the pathologies of hypoperfusion-induced animal AAA are consistent with those of human AAA. Similar to human AAA, aortic wall dilation [10], aneurysm rupture [10], adipogenesis in the adventitial wall [11-13], the presence of intraluminal thrombus [6,14], vascular wall thickness [15], medial wall thinning with smooth muscle cell (SMC) depletion [16], degradation of collagen and elastin fibers [10], gelatinolytic activity [17,18], oxidative stress due to the increased production of reactive oxygen species (ROS) [19,20], and VV stenosis [7] have been reported in hypoperfusion-induced AAA animal models $[8,9,21]$. Levels of hypoxiainducible factor- $1 \alpha$ (HIF-1 $\alpha)$ [22], matrix metalloproteinase (MMP)-2 [17], MMP-9 [17], MMP-12 [23], M1 [24] and M2 [25] macrophages, and monocyte chemotactic protein-1 (MCP-1) [26], which are increased in the human abdominal aortic wall, were also significantly increased in the aneurysmal wall (the dilated region) of the hypoperfusion-induced AAA animal model compared with the non-dilated normal region. Alpha-smooth muscle actin $(\alpha-S M A)+$ cells (contractile SMCs) in the medial wall, which are decreased in human AAA [27], were significantly decreased in the hypoperfusion-induced aortic wall. These reports suggest that hypoperfusion in the aortic wall may be an important factor in AAA formation. However, the pathological cascade following hypoperfusion remains largely unknown. Time-dependent pathological analysis is effective for identifying hypoperfusioninduced factors that can be closely associated with AAA development. In this study, we evaluated the time-dependent pathological changes in hypoperfusion-induced walls to clarify the mechanisms underlying hypoperfusion-induced AAA formation.

\section{Materials and Methods}

\subsection{Animals}

All animal experiments were approved by the Kindai University Animal Care and Use Committee and performed according to the Kindai University Animal Experimentation Regulations (approval number: KAAG-31-006). Six-week-old male Sprague-Dawley rats (Japan SLC, Inc., Shizuoka, Japan) were maintained in a room at $25 \pm 1{ }^{\circ} \mathrm{C}$ with a 12 -h light and 12-h dark cycle with free access to food and water. To collect aortic tissue and evaluate the pathology at several points from the induction of hypoperfusion to 28 days later, rats were divided into day $0(n=7)$, day $2(n=6)$, day $3(n=5)$, day $5(n=6)$, day $7(\mathrm{n}=6)$, day $10(\mathrm{n}=5)$, day $14(\mathrm{n}=6)$, day $21(\mathrm{n}=14)$, and day $28(\mathrm{n}=7)$ groups. In the experiment to evaluate aortic pathology within a short period, rats were divided to $0 \mathrm{~h}$ $(\mathrm{n}=6), 3 \mathrm{~h}(\mathrm{n}=7), 6 \mathrm{~h}(\mathrm{n}=6)$, and $24 \mathrm{~h}(\mathrm{n}=7)$ groups. After a 1-week habituation period, the abdominal aorta was subjected to hypoperfusion by ligation of the aortic wall to induce AAA. After the induction of hypoperfusion, the animal was sacrificed and the abdominal aorta was collected after 2, 3, 5, 7, 10, 14, 21, and 28 days according to the assigned group. In the experiment within a short period, the animal was sacrificed and the abdominal aorta was collected after 3,6 , and $24 \mathrm{~h}$ after treatment. In the day 0 and $0 \mathrm{~h}$ groups, the abdominal aorta in which hypoperfusion was not induced was collected. All surgeries were performed under anesthesia with minimal suffering.

\subsection{Induction of Hypoperfusion in the Abdominal Aortic Wall}

Hypoperfusion in the aortic wall was induced as described in previous studies $[9,21,28]$. The infrarenal aorta was exfoliated from the perivascular adipose tissue (Figure S1A), and vessels branching were ligated with 5-0 silk sutures (Akiyama Seisakusyo Co., Tokyo, Japan) to block the blood supply (Figure S1B). To block aortic blood flow, the aorta was 
ligated just below the renal artery and just above the bifurcation of the aorta (Figure S1C). A small incision was created by cutting the aortic wall (Figure S1D), and a polyurethane catheter (Medikit, Tokyo, Japan) shortened to $9 \mathrm{~mm}$ in length, was inserted (Figure S1E). The incision was repaired with a 6-0 monofilament suture (Alfresa Pharma, Osaka, Japan) (Figure S1F). The aortic wall was ligated over the inserted catheter using a 5-0 silk suture (Figure S1G). The 5-0 silk suture to block the blood in the aorta was removed to restore the blood flow (Figure $\mathrm{S} 1 \mathrm{H}$ ).

\subsection{Histological Analysis}

The diameter of the abdominal aorta was measured using digital calipers (A\&D, Tokyo, Japan). Isolated tissues were fixed in $4 \%$ paraformaldehyde (PFA) (Nacalai Tesque, Kyoto, Japan), soaked in sucrose $(10 \%, 15 \%$, and $20 \%)$, and embedded in O.C.T. compound (Sakura Finetek Japan Co., Ltd., Tokyo, Japan). These tissue samples were then stored at $-80^{\circ} \mathrm{C}$ until use.

Isolated aorta cross-sections (10 $\mu \mathrm{m}$ thick) were prepared using a cryostat (CM1850; Leica Microsystems, Wetzlar, Germany) and mounted on glass slides. Aortic walls were visualized with hematoxylin-eosin, picrosirius red, Elastica van Gieson, and immunohistochemical staining. Immunohistochemical staining was performed as described in previous studies $[6,18,25]$ using antibodies for the following proteins: rabbit anti-MMP-2 (1:50; Thermo Scientific, San Jose, CA, USA), goat anti-MMP-9 (1:50; Santa Cruz Biotechnology, Dallas, TX, USA), rabbit anti-MMP-12 (1:100; Bioss Antibodies, Woburn, MA, USA), rabbit anti-neutrophil elastase (1:100; Bioss Antibodies), mouse anti-monocytes/macrophages (Mac387) (1:50; Bio-Rad Laboratories, Hercules, CA, USA), rabbit anti-CD163 (1:100; Bioss Antibodies), rabbit anti- MCP-1 (1:50; Bioss Antibodies), mouse anti- $\alpha$-SMA (1:400; Santa Cruz Biotechnology), mouse anti-non-muscle myosin heavy chain (SMemb) (1:100; Yamasa, Chiba, Japan), mouse anti-angiotensinogen (1:50; Novus Biologicals, Littleton, CO, USA), rabbit anti-angiotensin II (AngII) type 1 (AT1) receptor (1:100; Advanced Targeting Systems, San Diego, CA, USA), rabbit anti-endothelin-1 (ET-1) (1:100; Abcam, Tokyo, Japan), and rabbit anti-malondialdehyde (MDA) (1:100; Abcam). Quantitative analyses of the immunohistochemical staining were performed using ImageJ software (National Institutes of Health, Bethesda, MD, USA). The area of positive staining in immunohistochemistry was calculated by binarizing the image into black and white using ImageJ. Sections of the negative control were not subjected to the primary antibodies.

\subsection{Microscopy}

Aortic wall sections were observed under an optical microscope (CX23, Olympus Corporation, Tokyo, Japan) with a $\times 40$ objective, connected to a camera (E-620, Olympus Corporation, Tokyo, Japan) with a $4032 \times 3024$ pixel resolution. Immunofluorescence staining was evaluated using a fluorescence microscope (ECLIPSE E200, Nikon Corporation, Tokyo, Japan) with a $\times 10$ objective, connected to Basler PowerPack for microscopy with a microscopy pulse (Basler AG, Ahrensburg, Germany). Basler microscopy software (Version 1.1, Basler AG) was used for image acquisition. The microscope was equipped with a fluorescence illumination system (E2-FM, Nikon Corporation, Tokyo, Japan) with a DAPI filter, FITC filter, and Texas red filter.

\subsection{Statistical Analyses}

Values are expressed as mean \pm SEM. Statistically significant differences were determined using the steel test and Mann-Whitney $U$ test. Statistical significance was set at $p<0.05$. Statistical analyses were performed using StatView software (version 5.0; SAS Institute, Cary, NC, USA) and EZR software [29]. 


\section{Results}

\subsection{Protein Levels in AAA-Related Factors in the Hypoperfusion-Induced Animal Model}

Before the time-dependent pathological analysis of AAA wall formation in the hypoperfusion-induced animal model, immunohistochemical analyses of SMemb, neutrophil elastase, angiotensinogen, AT1 receptor, MDA, and ET-1 were performed to elucidate the precise effect of hypoperfusion on the aortic wall on 28 days after the induction of hypoperfusion (Figure 1 and Figure S2). Positive areas for SMemb+ cells (synthetic SMCs), neutrophil elastase, angiotensinogen, AT1 receptor, MDA, and ET-1 were significantly increased in the hypoperfusion-induced AAA wall (Figure 1).
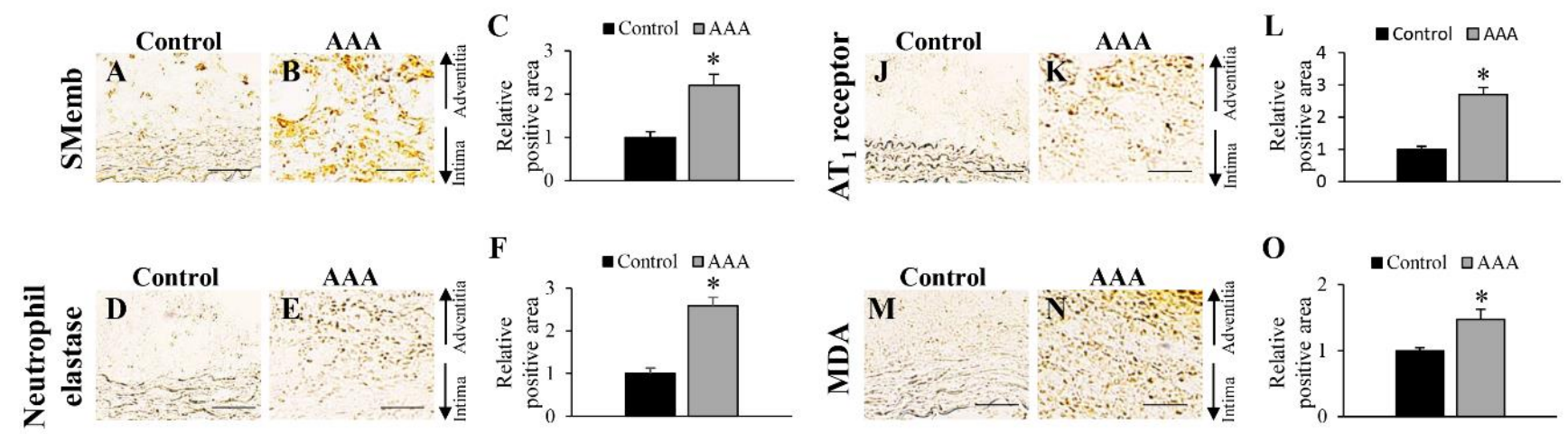

$\mathbf{F}$
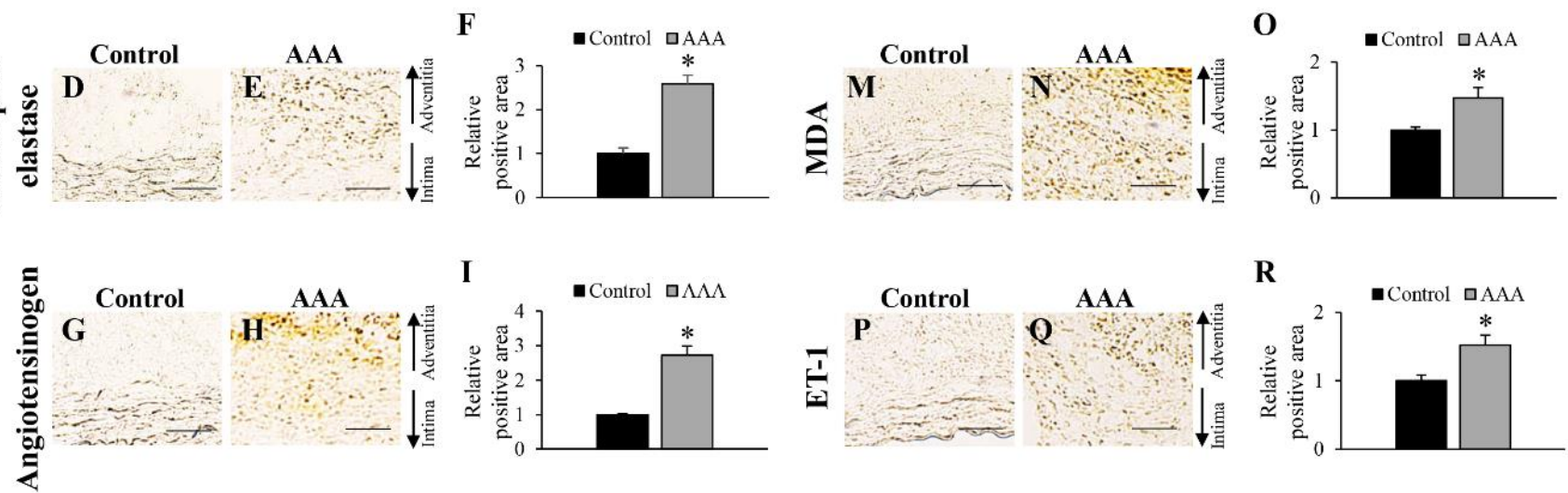

Figure 1. Positive areas for synthetic vascular smooth muscle (SMemb), neutrophil elastase, angiotensinogen, angiotensin II type $1\left(\mathrm{AT}_{1}\right)$ receptor, malondialdehyde (MDA), and endothelin-1 (ET-1) on 28 days after the induction of hypoperfusion. (A,B) Representative images of the immunostaining for SMemb (scale bar $=50 \mu \mathrm{m}$ ). (C) Quantification of areas positive for SMemb in the vascular wall. (D,E) Representative images of the immunostaining for neutrophil elastase (scale bar $=50 \mu \mathrm{m})$. (F) Quantification of areas positive for neutrophil elastase in the vascular wall. $(\mathbf{G}, \mathbf{H})$ Representative images of the immunostaining for angiotensinogen (scale bar $=50 \mu \mathrm{m}$ ). (I) Quantification of areas positive for angiotensinogen in the vascular wall. $(\mathbf{J}, \mathbf{K})$ Representative images of the immunostaining for $\mathrm{AT}_{1}$ receptor (scale bar $\left.=50 \mu \mathrm{m}\right)$. (L) Quantification of areas positive for $\mathrm{AT}_{1}$ receptor in the vascular wall. $(\mathbf{M}, \mathbf{N})$ Representative images of the immunostaining for MDA (scale bar $=50 \mu \mathrm{m})$. (O) Quantification of areas positive for MDA in the vascular wall. $(\mathbf{P}, \mathbf{Q})$ Representative images of the immunostaining for ET-1 (scale bar $=50 \mu \mathrm{m}$ ). (R) Quantification of areas positive for ET-1 in the vascular wall. Data are expressed as the mean \pm SEM. ${ }^{*} P<0.05$ versus control wall. SMemb and neutrophil elastase: control wall $(n=9)$ and AAA wall $(\mathrm{n}=10)$, AGT and $\mathrm{AT}_{1}$ receptor: control wall $(\mathrm{n}=8)$ and AAA wall $(\mathrm{n}=10)$, MDA: control wall $(\mathrm{n}=10)$ and AAA wall $(\mathrm{n}=12)$, and ET-1: control wall $(\mathrm{n}=9)$ and AAA wall $(\mathrm{n}=14)$.

\subsection{Time-Dependent Changes in AAA-Related Factors in the Hypoperfusion-Induced Animal Model}

Next, we performed a time-dependent pathological analysis of AAA-related factors in the aortic wall in the hypoperfusion-induced animal model. The thickness of the medial wall significantly decreased from the 3rd to the 28th day after aortic wall ligation to induce hypoperfusion (Figure 2A-I,S). The collagen-positive area significantly decreased from the 5 th to the 28th day after aortic wall ligation (Figure 2J-S). AAA formation was observed from the 10th to the 28th day after the aortic wall ligation (Figure $2 \mathrm{~S}$ and Figure S3). 

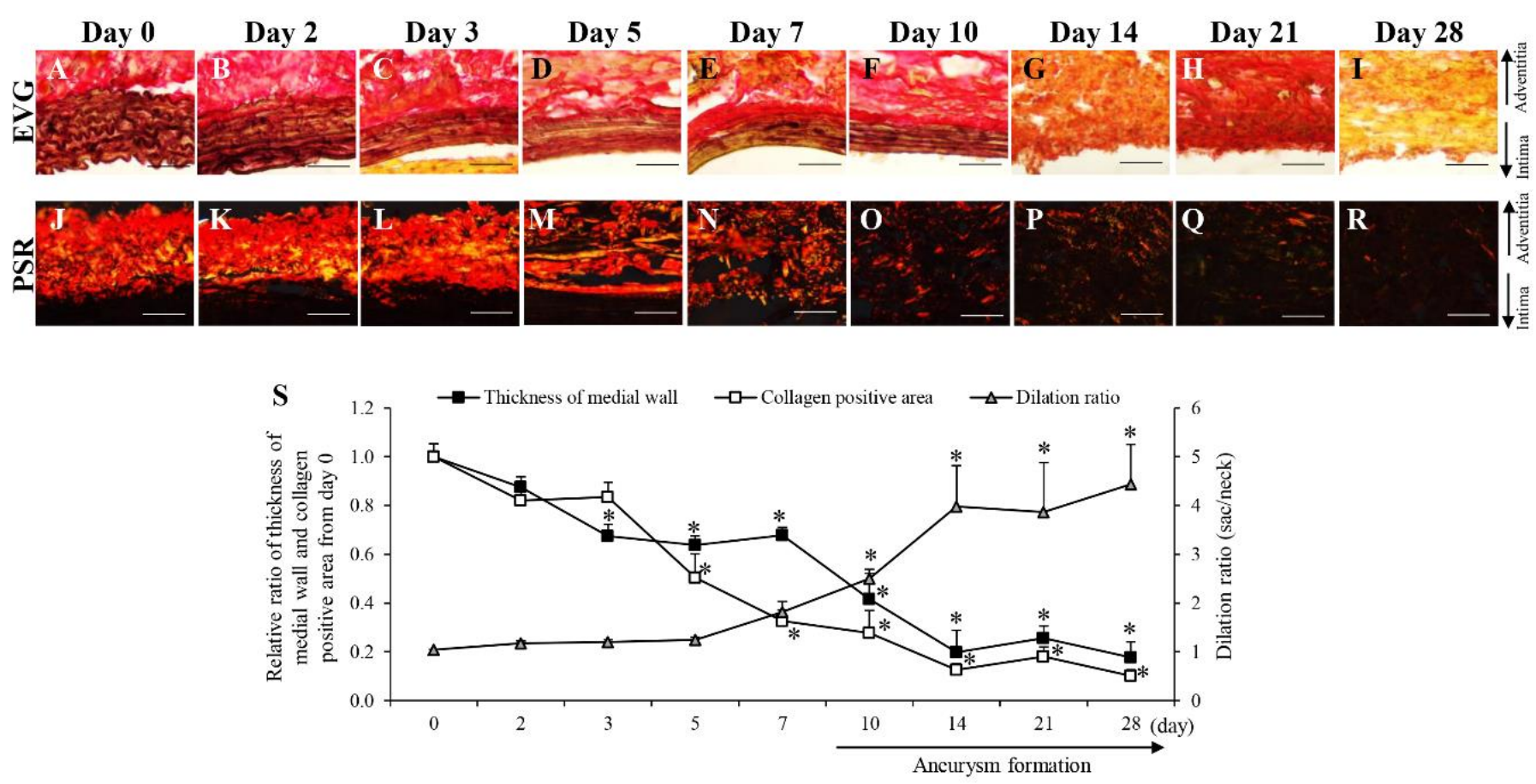

Figure 2. Time-dependent changes of thickness of medial wall and collagen positive area. (A-I) Representative images of the Elastica van Gieson (EVG) staining (scale bar $=50 \mu \mathrm{m}) .(\mathbf{J}-\mathbf{R})$ Representative images of the picrosirius red (PSR) staining (scale bar $=50 \mu \mathrm{m}$ ). (S) Quantification of the relative ratio from day 0 of thickness of medial wall, collagen positive area and dilation ratio in the vascular wall. Data are expressed as the mean \pm SEM. ${ }^{*} P<0.05$ versus day 0 . Day $0(n=7)$, day 2 $(n=6)$, day $3(n=5)$, day $5(n=6)$, day $7(n=6)$, day $10(n=5)$, day $14(n=6)$, day $21(n=14)$, and day $28(n=7)$.

The areas positive for MMP-2, MMP-9, and MMP-12 were significantly increased from the 2nd to the 28th day after aortic wall ligation (Figures S4 and S5A-I,S). To investigate their expression within a short period, time-dependent analyses of MMP-2, MMP-9, and MMP-12 from 0 to $24 \mathrm{~h}$ after aortic wall ligation were performed (Figure 3). Areas positive for MMP-2, MMP-9, and MMP-12 significantly increased from $6 \mathrm{~h}$ after aortic wall ligation (Figure 3). The neutrophil elastase-positive area significantly increased from the 3rd to the 28th day after aortic wall ligation (Figure S4J-S). Mac387+ cells (M1 macrophages) showed a significant increase from the 2nd to the 28th day after aortic wall ligation (Figure S6A-I,S). Moreover, Mac387+ cells significantly increased from $6 \mathrm{~h}$ after aortic wall ligation (Figure 4A-D,M). CD163+ cells (M2 macrophages) significantly increased from the 21st to the 28th day after aortic wall ligation (Figure S6J-S). The area positive for MCP-1 significantly increased from the 2nd to the 28th day after the induction of hypoperfusion and significantly increased from $6 \mathrm{~h}$ after aortic wall ligation (Figure S7 and Figure 4E-H,M). Alpha-SMA+ cells (contractile SMCs) in the medial wall significantly decreased from the 3rd to the 28th day after aortic wall ligation (Figure S8A-I,S). Conversely, SMemb+ cells (synthetic SMCs) significantly increased from the 2nd to the 28th day after aortic wall ligation (Figure S8J-S). The positive area for SMemb+ cells did not change until $24 \mathrm{~h}$ (Figure $4 \mathrm{I}-\mathrm{M}$ ). The positive areas for angiotensinogen significantly increased from the 3rd to the 28th day after aortic wall ligation (Figure S9A-I, S). The positive areas for AT1 receptor, ET-1, and MDA were significantly increased from the 2nd to the 28th day after aortic wall ligation (Figures S9J-S and S10). In addition, the positive areas for the AT1 receptor, ET-1, and MDA significantly increased at $3 \mathrm{~h}$ after aortic wall ligation (Figure 5). 

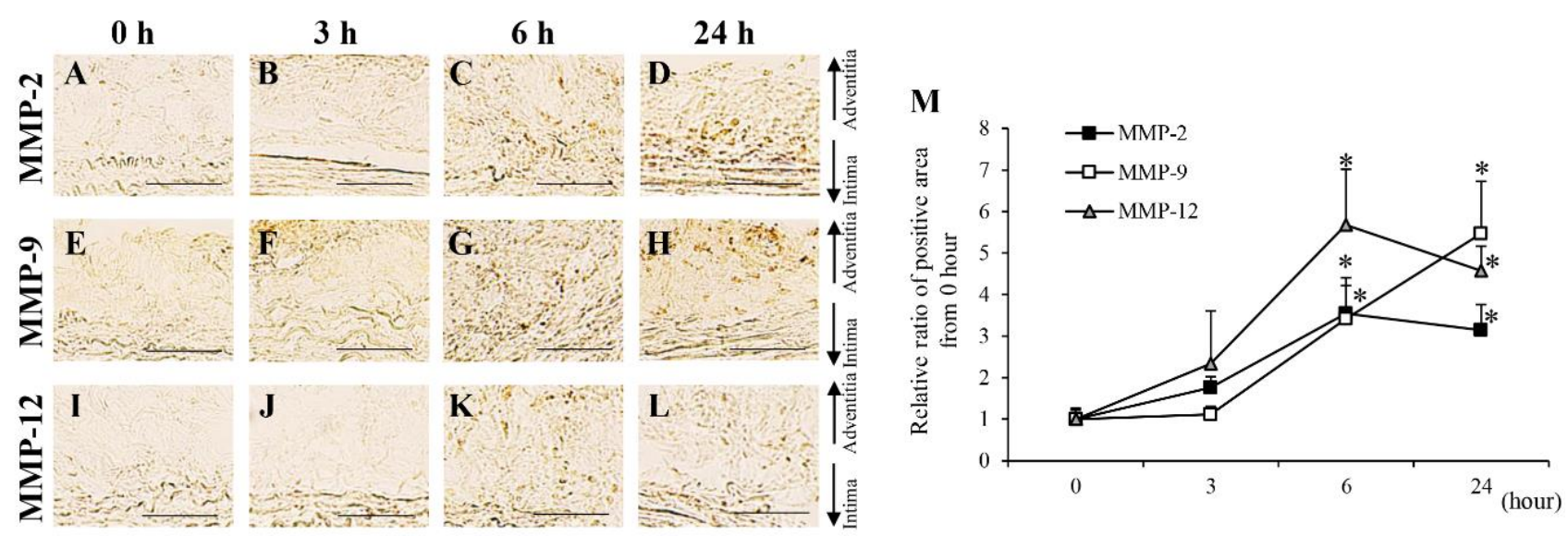

Figure 3. Time-dependent changes of matrix metalloproteinase (MMP)-2, MMP-9 and MMP-12 from 0 to 24 h. (A-D) Representative images of the immunostaining for MMP-2 (scale bar $=50 \mu \mathrm{m})$. (E-H) Representative images of the immunostaining for MMP-9 (scale bar $=50 \mu \mathrm{m}$ ). (J-L) Representative images of the immunostaining for MMP-12 (scale bar $=50 \mu \mathrm{m})$. (M) Quantification of the relative ratio from $0 \mathrm{~h}$ of the areas positive for MMP-2, MMP-9, and MMP-12 in the vascular wall. Data are expressed as the mean \pm SEM. ${ }^{*} P<0.05$ versus $0 \mathrm{~h}$. MMP-2: $0 \mathrm{~h}(\mathrm{n}=6), 3 \mathrm{~h}(\mathrm{n}=7), 6 \mathrm{~h}(\mathrm{n}=5)$, and $24 \mathrm{~h}(\mathrm{n}=7)$, MMP-9: $0 \mathrm{~h}(\mathrm{n}=6), 3 \mathrm{~h}(\mathrm{n}=5), 6 \mathrm{~h}(\mathrm{n}=6)$, and $24 \mathrm{~h}(\mathrm{n}=6)$, and MMP-12: $0 \mathrm{~h}(\mathrm{n}=6), 3 \mathrm{~h}(\mathrm{n}=7), 6 \mathrm{~h}(\mathrm{n}=6)$, and $24 \mathrm{~h}(\mathrm{n}=7)$.
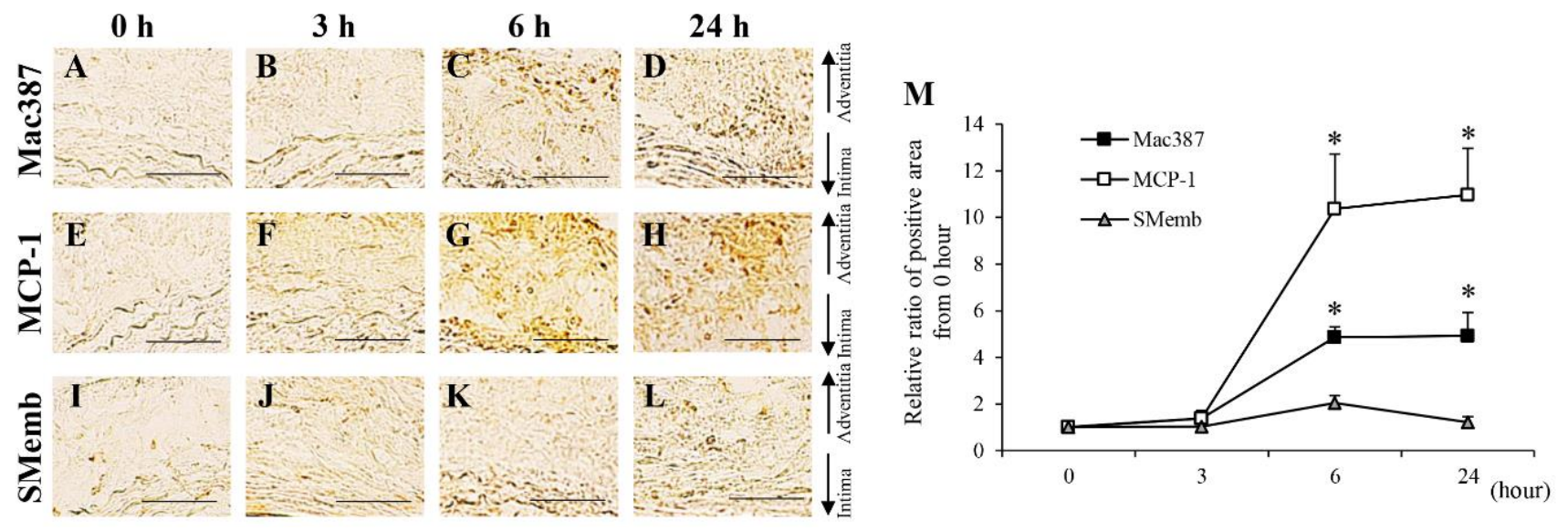

Figure 4. Time-dependent changes of mac387 ${ }^{+}$macrophage, monocyte chemoattractant protein-1 (MCP-1) and synthetic vascular smooth muscle (SMemb) from 0 to $24 \mathrm{~h}$. (A-D) Representative images of the immunostaining for mac387 (scale bar $=50 \mu \mathrm{m})$. (E-H) Representative images of the immunostaining for MCP-1 (scale bar $=50 \mu \mathrm{m})$. (J-L) Representative images of the immunostaining for SMemb (scale bar $=50 \mu \mathrm{m})$. (M) Quantification of the relative ratio from $0 \mathrm{~h}$ of the areas positive for mac387, MCP-1, and SMemb in the vascular wall. Data are expressed as the mean $\pm \mathrm{SEM}$. ${ }^{*} P<0.05$ versus $0 \mathrm{~h}$. Mac387: $0 \mathrm{~h}(\mathrm{n}=5), 3 \mathrm{~h}(\mathrm{n}=6), 6 \mathrm{~h}(\mathrm{n}=5)$, and $24 \mathrm{~h}(\mathrm{n}=5)$, MCP-1: $0 \mathrm{~h}(\mathrm{n}=6), 3 \mathrm{~h}(\mathrm{n}=5), 6 \mathrm{~h}(\mathrm{n}=6)$, and $24 \mathrm{~h}(\mathrm{n}=6)$, and SMemb: $0 h(n=6), 3 h(n=6), 6 h(n=6)$, and $24 h(n=6)$.

\subsection{Colocalization Studies of AAA-Related Factors with $\alpha-S M A+$ Cells and Mac387+Cells}

To understand the AAA pathology at the initial stage, we investigated the colocalization of AAA-related factors with $\alpha$-SMA+ cells and Mac387+ cells. Mac387+ cells were significantly detected at $6 \mathrm{~h}$ after induction of hypoperfusion and were analyzed in $6 \mathrm{~h}$. HIF-1 $\alpha$ was colocalized with $\alpha$-SMA + cells in $3 \mathrm{~h}$, but not in Mac387+ cells (Figure 6). AT1 receptor was colocalized with $\alpha-S M A+$ cells both at $0 \mathrm{~h}$ and $3 \mathrm{~h}$, and with Mac387+ cells in $6 \mathrm{~h}$ (Figure S11). ET-1 and MDA were colocalized with $\alpha$-SMA+ cells in $3 \mathrm{~h}$, but not in Mac387+ cells (Figures S12 and S13). MMP-2 was colocalized with $\alpha$-SMA+ cells both at 0 and $3 \mathrm{~h}$, but not with Mac387+ cells (Figure S14). MMP-9 was colocalized with $\alpha$-SMA+ cells in both $3 \mathrm{~h}$ and Mac387+ cells at $6 \mathrm{~h}$ (Figure S15). MMP-12 did not colocalize with $\alpha$-SMA+ cells at both $0 \mathrm{~h}$ and $3 \mathrm{~h}$, but did with Mac387+ cells in $6 \mathrm{~h}$ (Figure S16). 
MCP-1 was colocalized with $\alpha$-SMA+ cells both at 0 and $3 \mathrm{~h}$, but not with Mac387+ cells (Figure S17). Neutrophil elastase did not colocalize with either $\alpha$-SMA+ or Mac387+ cells (Figure S18). Angiotensinogen was colocalized with $\alpha$-SMA+ cells both at $0 \mathrm{~h}$ and $3 \mathrm{~h}$, but not with Mac387+ cells (Figure S19). The data are summarized in Table 1.
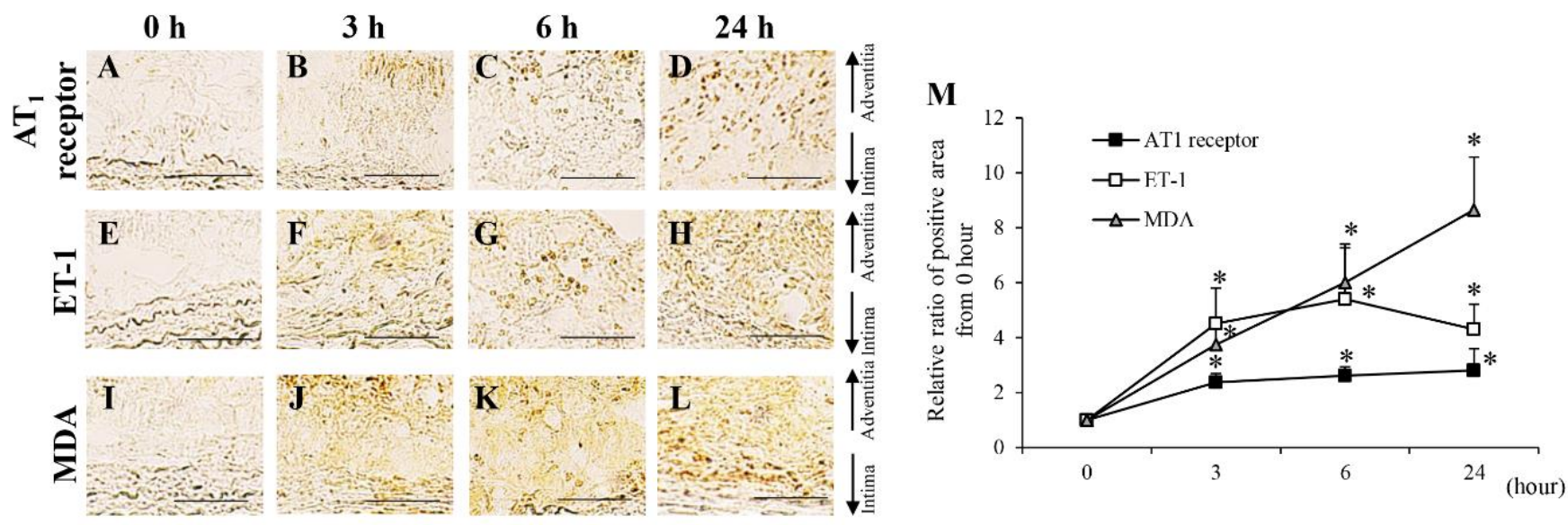

Figure 5. Time-dependent changes of angiotensin II type 1 ( $\left.\mathrm{AT}_{1}\right)$ receptor, endothelin-1 (ET-1) and malondialdehyde (MDA) from 0 to $24 \mathrm{~h}$. (A-D) Representative images of the immunostaining for $\mathrm{AT}_{1}$ receptor (scale bar $\left.=50 \mu \mathrm{m}\right)$. (E-H) Representative images of the immunostaining for ET-1 (scale bar $=50 \mu \mathrm{m})$. (J-L) Representative images of the immunostaining for MDA (scale bar $=50 \mu \mathrm{m}$ ). (M) Quantification of the relative ratio from $0 \mathrm{~h}$ of the areas positive for $\mathrm{AT}_{1}$ receptor, ET- 1 , and MDA in the vascular wall. Data are expressed as the mean \pm SEM. ${ }^{*} P<0.05$ versus $0 \mathrm{~h} . \mathrm{AT}_{1}$ receptor: $0 \mathrm{~h}(\mathrm{n}=6), 3 \mathrm{~h}(\mathrm{n}=6)$, $6 \mathrm{~h}(\mathrm{n}=5)$, and $24 \mathrm{~h}(\mathrm{n}=7)$, ET- $1: 0 \mathrm{~h}(\mathrm{n}=6), 3 \mathrm{~h}(\mathrm{n}=7), 6 \mathrm{~h}(\mathrm{n}=5)$, and $24 \mathrm{~h}(\mathrm{n}=7)$, and MDA: $0 \mathrm{~h}(\mathrm{n}=6), 3 \mathrm{~h}(\mathrm{n}=6), 6 \mathrm{~h}$ $(\mathrm{n}=6)$, and $24 \mathrm{~h}(\mathrm{n}=7)$.
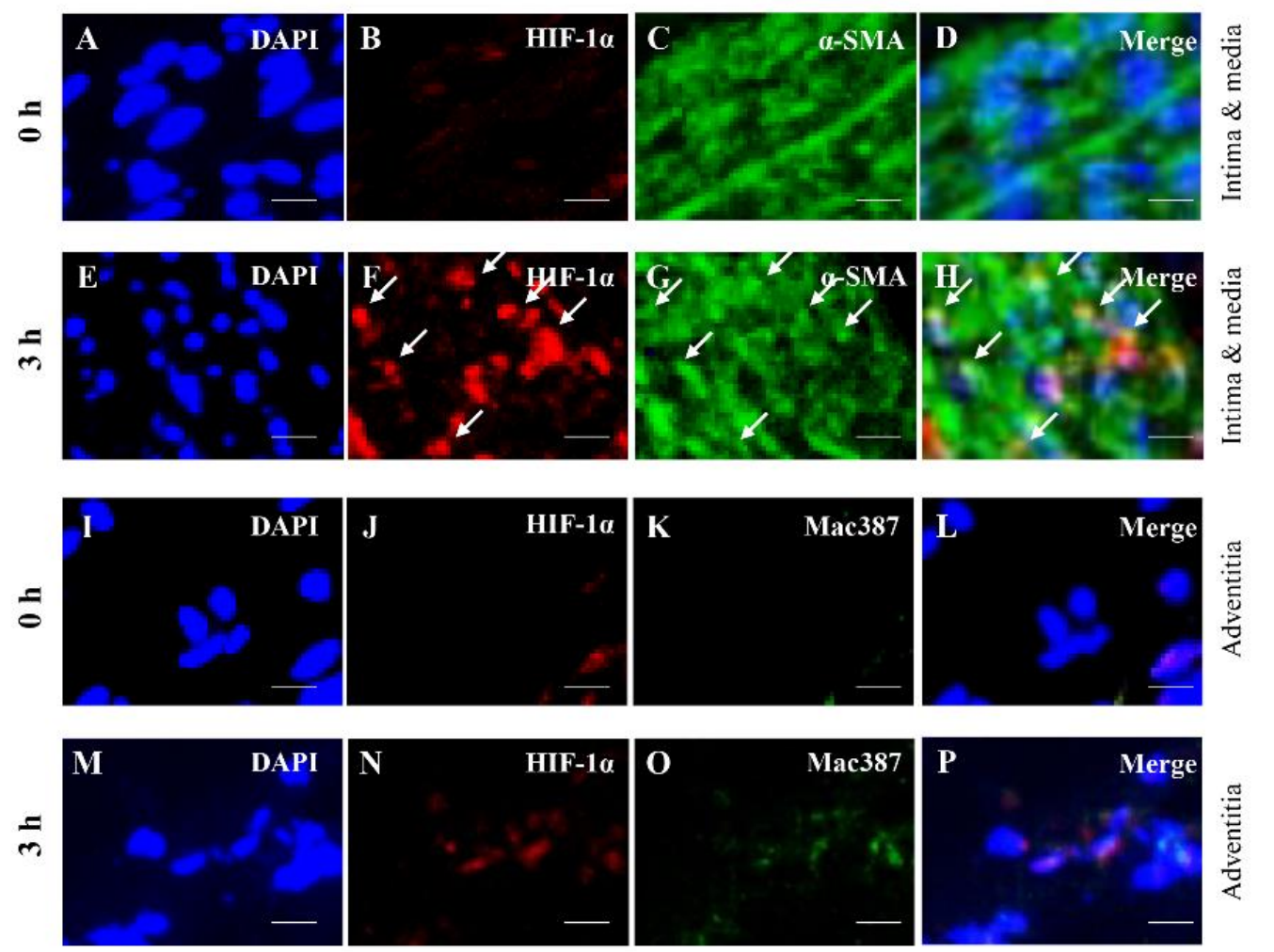

Figure 6. Localization of hypoxia inducible factor (HIF)- $1 \alpha, \alpha$-smooth muscle actin $(\alpha-\mathrm{SMA})^{+}$cells and mac387 ${ }^{+}$ macrophages in the aortic wall. Double-immunostaining for HIF- $1 \alpha$ and $\alpha$-SMA in $0 \mathrm{~h}(\mathbf{A}-\mathbf{D})$ and $3 \mathrm{~h}(\mathbf{E}-\mathbf{H})$. The white arrows indicate the co-localized region. Double-immunostaining for HIF- $1 \alpha$ and mac $387^{+}$macrophages in $0 \mathrm{~h}(\mathbf{I}-\mathbf{L})$ and $6 \mathrm{~h}$ (M-P). Scale bar $=15 \mu \mathrm{m} .0 \mathrm{~h}(\mathrm{n}=5), 3 \mathrm{~h}(\mathrm{n}=5)$, and $6 \mathrm{~h}(\mathrm{n}=5)$. 
Table 1. Localization of abdominal aortic aneurysm-related factors.

\begin{tabular}{ccccc}
\hline & \multicolumn{2}{c}{ Contractile SMC $(\alpha-S M A)$} & \multicolumn{2}{c}{ M1 Macrophage (Mac387) } \\
& $\mathbf{0 ~ h}$ & $\mathbf{3 ~ h}$ & $\mathbf{0 ~ h}$ & $\mathbf{6 ~ h}$ \\
\hline HIF-1 $\alpha$ & - & + & - & - \\
$\mathrm{AT}_{1}$ receptor & + & + & - & + \\
ET-1 & - & + & - & - \\
MDA & - & + & - & - \\
MMP-2 & + & + & - & - \\
MMP-9 & - & + & - & + \\
MMP-12 & - & - & - & + \\
MCP-1 & + & + & - & - \\
Neutrophil elastase & - & - & - & - \\
Angiotensinogen & + & + & - & - \\
\hline+ co-localization in the aortic wall. & & &
\end{tabular}

\section{Discussion}

In this study, we performed time-dependent pathological analyses of the hypoperfusioninduced aortic walls to clarify the molecular mechanisms correlating hypoperfusion and AAA formation. A comparison of the pathological events of a hypoperfusion-induced AAA animal model and human AAA is shown in Table 2. Time-dependent changes in pathologies and proteins, including those in previous studies, were sorted by the dynamically changing time of each factor (Table $3 \mathrm{~A}, \mathrm{~B})$. Five dynamic changes were observed in the evaluated AAA-related factors after the induction of hypoperfusion (Table 3B).

Table 2. Comparison of pathological features between hypoperfusion-induced model and human abdominal aortic aneurysm (AAA).

(A) Pathological events in human AAA and hypoperfusion-induced model.

\begin{tabular}{|c|c|c|c|c|}
\hline Pathological feature & Human AAA & Reference & Hypoperfusion model & Reference \\
\hline Aortic dilation & + & Lancet [10] & + & PLoS ONE [8] \\
\hline Aneurysm rupture & + & Lancet [10] & + & $\begin{array}{c}\text { Sci Rep [9], J Oleo } \\
\text { Sci [21] }\end{array}$ \\
\hline Adipogenesis & + & $\begin{array}{l}\text { J Vasc Res [13], J Vasc Surg. [11], } \\
\text { Acta Biomater [12] }\end{array}$ & + & $\begin{array}{c}\text { Sci Rep [9], J Oleo } \\
\text { Sci [21], } \\
\text { Adipocyte [30] }\end{array}$ \\
\hline Intraluminal thrombus & + & J Vasc Surg. [14], J Vasc Surg. [6] & + & PLoS ONE [8] \\
\hline Vascular wall thickening & + & J Surg. Case Rep [15] & + & Sci Rep [9] \\
\hline Medial wall thinning & + & Circulation [16] & + & Sci Rep [9] \\
\hline Collagen fiber degradation & + & Lancet [10] & + & PLoS ONE [8] \\
\hline Elastin fiber degradation & + & Lancet [10] & + & PLoS ONE [8] \\
\hline Gelatinolytic activity & + & J Vasc Surg. [17], World J Surg. [18] & + & PLoS ONE [8] \\
\hline Oxidative stress & + & $\begin{array}{c}\text { Clin Sci (Long) [19], In J } \\
\text { Cardiol [20] }\end{array}$ & + & $\begin{array}{l}\text { Biosci Biotechnol } \\
\text { Biochem [31] }\end{array}$ \\
\hline Stenosis of vasa vasorum & + & PLoS ONE [7] & + & PLoS ONE [8] \\
\hline Angiogenesis & + & $\begin{array}{c}\text { J Am Heart Assoc [22], PLoS } \\
\text { ONE [32] }\end{array}$ & + & Figure 7 \\
\hline Atherosclerosis & + & Curr Opin Cardiol [33] & - & \\
\hline Calcification & + & $\begin{array}{c}\text { Int Angiol [34], Atherosclerosis [35], } \\
\text { Circ J [36] }\end{array}$ & - & \\
\hline
\end{tabular}


Table 2. Cont.

(B) Protein expressions of AAA-related factors in human AAA and hypoperfusion-induced model.

\begin{tabular}{|c|c|c|c|c|}
\hline Pathological feature & Human AAA & Reference & Hypoperfusion model & Reference \\
\hline HIF- $1 \alpha$ & $\uparrow$ & J Am Heart Assoc [22] & $\uparrow$ & PLoS ONE [8] \\
\hline MMP-2 & $\uparrow$ & $\begin{array}{c}\text { J Vasc Surg. [17], Ann N Y Acad } \\
\text { Sci [37] }\end{array}$ & $\uparrow$ & $\begin{array}{l}\text { PLoS ONE [8], Sci Rep [9], J } \\
\text { Vasc Res [38], J Oleo Sci [39] }\end{array}$ \\
\hline MMP-9 & $\uparrow$ & $\begin{array}{l}\text { J Vasc Surg. [17], Ann N Y Acad } \\
\text { Sci [37] }\end{array}$ & $\uparrow$ & $\begin{array}{l}\text { PLoS ONE [8], Sci Rep [9], J } \\
\text { Vasc Res [38], J Oleo Sci [39] }\end{array}$ \\
\hline MMP-12 & $\uparrow$ & J Clin Invest [23] & $\uparrow$ & J Vasc Res [38], J Oleo Sci [39] \\
\hline M1 macrophage & $\uparrow$ & $\begin{array}{c}\text { Dis Markers [40], Arterioscler } \\
\text { Thromb Vasc Biol [24] }\end{array}$ & $\uparrow$ & $\begin{array}{l}\text { PLoS ONE [8], Sci Rep [9], J } \\
\text { Vasc Res [38], J Oleo Sci [39] }\end{array}$ \\
\hline M2 macrophage & $\uparrow$ & Int J Cardiol [25] & $\uparrow$ & Sci Rep [9] \\
\hline MCP-1 & $\uparrow$ & Am J Pathol [26] & $\uparrow$ & $\begin{array}{c}\text { Sci Rep [9], J Vasc Res [38], J } \\
\text { Oleo Sci [39] }\end{array}$ \\
\hline Contractile SMC & $\downarrow$ & Arterioscler Thromb Vasc Biol [27] & $\downarrow$ & PLoS ONE [8], Sci Rep [9] \\
\hline Synthetic SMC & $\uparrow$ & Cardiovasc Pathol [41] & $\uparrow$ & Figure $1 \mathrm{C}$ \\
\hline Neutrophil elastase & $\uparrow$ & Cardiovasc Surg. [42] & $\uparrow$ & Figure $1 \mathrm{~F}$ \\
\hline Angiotensinogen & $\uparrow$ & Atherosclerosis [43] & $\uparrow$ & Figure 1I \\
\hline $\mathrm{AT}_{1}$ receptor & $\uparrow$ & Atherosclerosis [43] & $\uparrow$ & Figure 1L \\
\hline MDA & $\uparrow$ & Arterioscler Thromb Vasc Biol [44] & $\uparrow$ & Figure 10 \\
\hline ET-1 & $?$ & & $\uparrow$ & Figure 1R \\
\hline
\end{tabular}

' $\rightarrow$ ' indicates no difference in sac wall compared to neck wall. ' $\uparrow$ ' or ' $\downarrow$ ' indicates $P<0.05$ versus neck wall. ' $\uparrow$ ' indicates significant increase and ' $\downarrow$ ' indicates significant decrease in sac wall compared to neck wall $(P<0.05$ versus neck wall). HIF- $1 \alpha$ : hypoxia-inducible factor- $1 \alpha$, MMP: matrix metalloproteinase, MCP-1: monocyte chemoattractant protein-1, SMC: smooth muscle cell, $\alpha$-SMA: $\alpha$-smooth muscle actin, $\mathrm{AT}_{1}$ : angiotensin II Type 1, MDA: malondialdehyde, ET-1: endothelin-1.

\section{a-SMA}
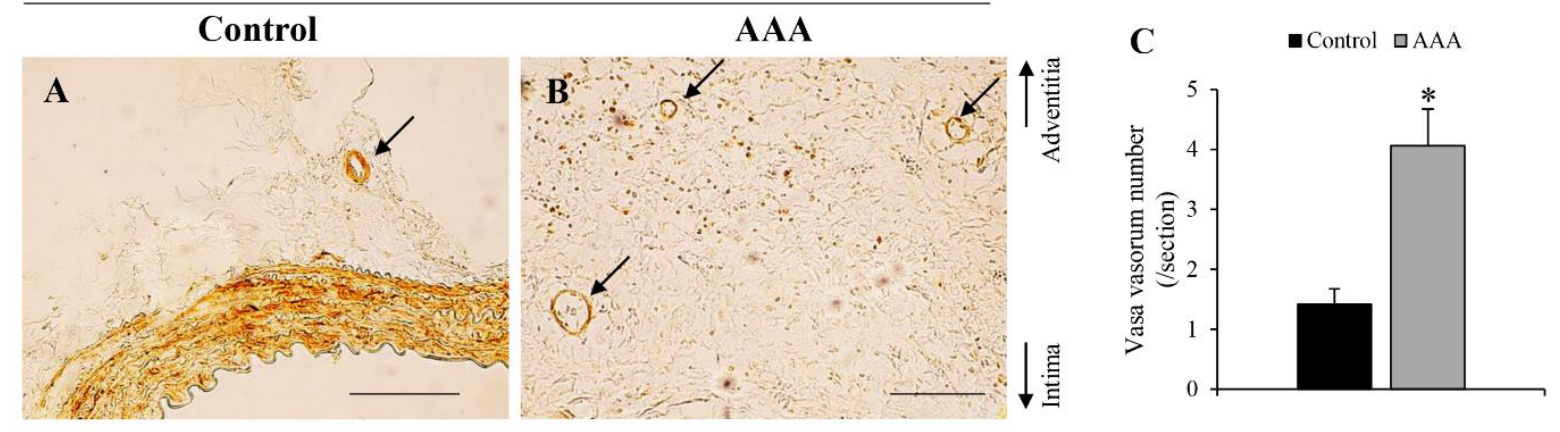

Figure 7. Observation of adventitial vasa vasorum (VV). Representative images of immunostaining for $\alpha$-smooth muscle actin in (A) control wall (scale bar $=100 \mu \mathrm{m})$. (B) AAA wall (scale bar $=200 \mu \mathrm{m})$. (C) VV number (/section) in the aortic wall. ${ }^{*} P<0.05$ versus control wall. Control wall $(n=12)$ and AAA wall $(n=17)$. 
Table 3. Time-dependent changes of abdominal aortic aneurysm-related factors in hypoperfusion-induced model.

\begin{tabular}{ccccccccccccccc}
\hline \multicolumn{10}{c}{ (A) Time-dependent changes of pathological events in hypoperfusion-induced model. } \\
\hline \multirow{2}{*}{ Pathology } & $\mathbf{0 ~ h}$ & $\mathbf{3 h}$ & $\mathbf{6 h}$ & $\mathbf{2 4} \mathbf{h}$ & Day 2 & Day 3 & Day 5 & Day 7 & Day 10 & Day 14 & Day 21 & Day 28 \\
\hline $\begin{array}{c}\text { Medial wall } \\
\text { thickness }\end{array}$ & $\rightarrow$ & $\rightarrow$ & $\rightarrow$ & $\rightarrow$ & $\rightarrow$ & $\downarrow$ & $\downarrow$ & $\downarrow$ & $\downarrow$ & $\downarrow$ & $\downarrow$ & $\downarrow$ \\
$\begin{array}{c}\text { Collagen fiber } \\
\text { degradation }\end{array}$ & $\rightarrow$ & $\rightarrow$ & $\rightarrow$ & $\rightarrow$ & $\rightarrow$ & $\rightarrow$ & $\uparrow$ & $\uparrow$ & $\uparrow$ & $\uparrow$ & $\uparrow$ & $\uparrow$ \\
AAA & $\rightarrow$ & $\rightarrow$ & $\rightarrow$ & $\rightarrow$ & $\rightarrow$ & $\rightarrow$ & $\rightarrow$ & $\rightarrow$ & $\uparrow$ & $\uparrow$ & $\uparrow$ & $\uparrow$ & \\
\hline
\end{tabular}

(B) Time-dependent changes of protein expressions of AAA-related factors in hypoperfusion-induced model.

\begin{tabular}{|c|c|c|c|c|c|c|c|c|c|c|c|c|c|}
\hline \multirow{2}{*}{ Protein } & \multicolumn{4}{|c|}{ Day 1} & \multirow[b]{2}{*}{ Day 2} & \multirow[b]{2}{*}{ Day 3} & \multirow[b]{2}{*}{ Day 5} & \multirow[b]{2}{*}{ Day 7} & \multirow[b]{2}{*}{ Day 10} & \multirow[b]{2}{*}{ Day 14} & \multirow[b]{2}{*}{ Day 21} & \multirow[b]{2}{*}{ Day 28} & \multirow{2}{*}{ Group } \\
\hline & $\mathrm{Oh}$ & $3 \mathrm{~h}$ & $6 \mathrm{~h}$ & $24 \mathrm{~h}$ & & & & & & & & & \\
\hline HIF- $1 \alpha$ & $\rightarrow$ & $\uparrow$ & $\uparrow$ & $\uparrow$ & $\uparrow$ & $\uparrow$ & $\uparrow$ & $\uparrow$ & $\uparrow$ & $\uparrow$ & $\uparrow$ & $\uparrow$ & \multirow{4}{*}{ First } \\
\hline $\mathrm{AT}_{1}$ receptor & $\rightarrow$ & $\uparrow$ & $\uparrow$ & $\uparrow$ & $\uparrow$ & $\uparrow$ & $\uparrow$ & $\uparrow$ & $\uparrow$ & $\uparrow$ & $\uparrow$ & $\uparrow$ & \\
\hline ET-1 & $\rightarrow$ & $\uparrow$ & $\uparrow$ & $\uparrow$ & $\uparrow$ & $\uparrow$ & $\uparrow$ & $\uparrow$ & $\uparrow$ & $\uparrow$ & $\uparrow$ & $\uparrow$ & \\
\hline MDA & $\rightarrow$ & $\uparrow$ & $\uparrow$ & $\uparrow$ & $\uparrow$ & $\uparrow$ & $\uparrow$ & $\uparrow$ & $\uparrow$ & $\uparrow$ & $\uparrow$ & $\uparrow$ & \\
\hline MMP-2 & $\rightarrow$ & $\rightarrow$ & $\uparrow$ & $\uparrow$ & $\uparrow$ & $\uparrow$ & $\uparrow$ & $\uparrow$ & $\uparrow$ & $\uparrow$ & $\uparrow$ & $\uparrow$ & \multirow{5}{*}{ Second } \\
\hline MMP-9 & $\rightarrow$ & $\rightarrow$ & $\uparrow$ & $\uparrow$ & $\uparrow$ & $\uparrow$ & $\uparrow$ & $\uparrow$ & $\uparrow$ & $\uparrow$ & $\uparrow$ & $\uparrow$ & \\
\hline \multirow{3}{*}{$\begin{array}{l}\text { MMP-12 } \\
\text { M1 macrophage } \\
\text { (Mac387) } \\
\text { MCP-1 }\end{array}$} & $\rightarrow$ & $\rightarrow$ & $\uparrow$ & $\uparrow$ & $\uparrow$ & $\uparrow$ & $\uparrow$ & $\uparrow$ & $\uparrow$ & $\uparrow$ & $\uparrow$ & $\uparrow$ & \\
\hline & $\rightarrow$ & $\rightarrow$ & $\uparrow$ & $\uparrow$ & $\uparrow$ & $\uparrow$ & $\uparrow$ & $\uparrow$ & $\uparrow$ & $\uparrow$ & $\uparrow$ & $\uparrow$ & \\
\hline & $\rightarrow$ & $\rightarrow$ & $\uparrow$ & $\uparrow$ & $\uparrow$ & $\uparrow$ & $\uparrow$ & $\uparrow$ & $\uparrow$ & $\uparrow$ & $\uparrow$ & $\uparrow$ & \\
\hline $\begin{array}{l}\text { Synthetic SMC } \\
\text { (SMemb) }\end{array}$ & $\rightarrow$ & $\rightarrow$ & $\rightarrow$ & $\rightarrow$ & $\uparrow$ & $\uparrow$ & $\uparrow$ & $\uparrow$ & $\uparrow$ & $\uparrow$ & $\uparrow$ & $\uparrow$ & Third \\
\hline \multirow{3}{*}{$\begin{array}{c}\text { Neutrophil elastase } \\
\text { Angiotensinogen } \\
\text { Contractile SMC } \\
(\alpha-S M A)\end{array}$} & $\rightarrow$ & $\rightarrow$ & $\rightarrow$ & $\rightarrow$ & $\rightarrow$ & $\uparrow$ & $\uparrow$ & $\uparrow$ & $\uparrow$ & $\uparrow$ & $\uparrow$ & $\uparrow$ & \multirow{3}{*}{ Forth } \\
\hline & $\rightarrow$ & $\rightarrow$ & $\rightarrow$ & $\rightarrow$ & $\rightarrow$ & $\uparrow$ & $\uparrow$ & $\uparrow$ & $\uparrow$ & $\uparrow$ & $\uparrow$ & $\uparrow$ & \\
\hline & $\rightarrow$ & $\rightarrow$ & $\rightarrow$ & $\rightarrow$ & $\rightarrow$ & $\downarrow$ & $\downarrow$ & $\downarrow$ & $\downarrow$ & $\downarrow$ & $\downarrow$ & $\downarrow$ & \\
\hline $\begin{array}{l}\text { M2 macrophage } \\
\text { (CD163) }\end{array}$ & $\rightarrow$ & $\rightarrow$ & $\rightarrow$ & $\rightarrow$ & $\rightarrow$ & $\rightarrow$ & $\rightarrow$ & $\rightarrow$ & $\rightarrow$ & $\rightarrow$ & $\uparrow$ & $\uparrow$ & Fifth \\
\hline
\end{tabular}

' $\uparrow$ ' or ' $\downarrow$ ' indicates $P<0.05$ versus day 0 (pre-induction of hypoperfusion). HIF-1 $\alpha$ : hypoxia-inducible factor- $1 \alpha$, MMP: matrix metalloproteinase, MCP-1: monocyte chemoattractant protein-1, SMC: smooth muscle cell, $\alpha$-SMA: $\alpha$-smooth muscle actin, $\mathrm{AT}_{1}$ : angiotensin II Type 1, ET-1: endothelin-1, MDA: malondialdehyde.

Levels of the AT1 receptor, ET-1, and MDA initially increased $3 \mathrm{~h}$ after the induction of hypoperfusion. The AT1 receptor is required for AngII-induced AAA formation [45]. AT1 receptors, including endothelial cells, SMCs, and macrophages, are detected in several cells of the arterial wall. AngII stimulates MCP-1 secretion [46], ROS production [47], and MMP2 expression in SMCs [48]. ET-1 is a 21-amino-acid peptide and is one of the most potent endogenous vasoconstrictors. ET-1 overexpression induces aneurysms in apolipoprotein E knockout mice with increased oxidative stress levels and monocyte/macrophage infiltration [49]. Similarly, plasma ET-1 levels [50,51] and aortic tissue AT1 receptor levels [43] are significantly increased in patients with AAA. MDA is an oxidative stress marker in AAA walls. Oxidative stress due to ROS production is involved in vascular injury and AAA development [52]. Oxidative stress is induced by endothelial dysfunction and nicotinamide adenine dinucleotide phosphate oxidase overexpression [53]. In our previous report, HIF- $1 \alpha$ levels were also increased $3 \mathrm{~h}$ after the induction of hypoperfusion [30]. HIF$1 \alpha$ is reportedly the upstream factor of the molecules involved in AAA development [22], including ET-1 [54]. These data suggest that hypoperfusion in the aortic wall first induces hypoxia and vasoconstriction-related factors (AT1 receptor and ET-1) related to increased oxidative stress and inflammation.

Second, $6 \mathrm{~h}$ after the induction of hypoperfusion, the levels of MMP-2, MMP-9, MMP12, Mac387+ macrophages (M1 macrophages), and MCP-1 significantly increased in the aortic walls. Increased levels of these AAA-related factors are consistent with findings in human AAA $[17,23,24,26,37,40]$. Oxidative stress due to ROS production in vascular SMCs reportedly induces excess MMP- 2 expression $[55,56]$. In addition, HIF- $1 \alpha$ induces MMP expression under hypoxic conditions [57]. As mentioned above, the increased levels in 
the second group can be associated with increased levels of factors in the first group and HIF- $1 \alpha$.

Third, synthetic SMC, SMemb+SMC, significantly increased 2 days after the induction of hypoperfusion. SMemb is a non-muscle myosin heavy chain abundantly expressed in SMCs in the immature aorta [58], and an increased level of SMemb+ SMC is consistent with human AAA [41]. The increased level of synthetic SMC may be associated with the decreased level of contractile SMC in the fourth group. A hypoperfusion-induced AAA model may reproduce both the increase in synthetic SMC and the decreased in contractile SMC observed in human AAA. Contractile SMCs regulate the diameter and blood flow of the normal aorta. In response to aortic injury, contractile SMC shifts the aorta from a contractile state to a synthetic state, known as "phenotypic switching" [59]. Synthetic SMCs can secrete various extracellular matrix proteins and MMP molecules. Phenotypic switching is involved in the development of AAA $[41,60]$. Ailawadi et al. reported that phenotypic switching is an early event in aortic aneurysms formed in an elastase-induced AAA animal model [61]. The same group reported the possibility that Krüppel-like factor 4 (KLF4) regulates SMC phenotype switching [60]. KLF4 is able to induce pluripotent stem cells [62] and HIF-1 $\alpha$ reportedly induces its expression in cancer cells [63], suggesting that hypoperfusion might be involved in KLF4 expression in the AAA wall.

Fourth, neutrophil elastase, angiotensinogen, and contractile SMC significantly changed 3 days after the induction of hypoperfusion. Changes in these AAA-related factors are consistent with those observed in human AAA [27,42,43]. Neutrophil elastase, which is released by activated neutrophils, plays an important role in the development of AAA [64,65]. It reportedly regulates the formation of neutrophil extracellular traps (NETs) [66], which play a critical role in the neutrophil-mediated development of AAA [67]. In sepsis-induced thrombus formation, HIF-1 $\alpha$ activation is associated with NET formation during thrombosis [68], suggesting that NETs are downstream factors of hypoperfusion. Angiotensinogen is involved in hypertension as a precursor of AngII [69]. The promoter domain of angiotensinogen contains a binding site for HIF- $1 \alpha$, which mediates the transcriptional activation of angiotensinogen [70]. A decreased level of contractile SMC might be associated with the phenotypic switching mentioned above.

Fifth, the number of M2 macrophages (CD163+ cells) significantly increased 21 days after AAA formation. The observation of M2 macrophages is consistent with the findings of a previous human AAA study [25]. M2 macrophages promote anti-inflammatory response [71] and angiogenesis [72]. Adventitial angiogenesis has been observed in human AAA [22,32]. In this experimental model, the VV count in the adventitial wall increased in the AAA wall (Figure 7 and Table 2A). The increased VV count might indicate a compensatory reaction to attenuate the hypoxic conditions in the AAA wall. HIF- $1 \alpha$ stimulates angiogenesis via the NF-E2-related factor 2/heme oxygenase-1 (HO-1) pathway [72]. HO-1 is involved in promoting macrophage differentiation into the M2 phenotype as well as other inducible factors, such as interleukins and micro RNAs [73,74].

Colocalization studies have suggested the mechanisms underlying the cascades of AAA pathology in the initial stage ( 0 to $6 \mathrm{~h}$ ). HIF- $1 \alpha$ was colocalized with $\alpha$-SMA+ cells in $3 \mathrm{~h}$, but not with Mac387+ cells, suggesting that hypoperfusion-induced hypoxia directly affects the activities of contractile SMCs in the initial stage of AAA. The expression of ET-1, MDA, and MMP-9 in contractile SMCs might be associated with hypoperfusion-induced expression of HIF-1 $\alpha$.

In this study, we showed the characteristic dynamics of human AAA-related factors using a hypoperfusion-induced animal model. To our knowledge, this is the first timedependent pathological study of an AAA animal model. Expression of HIF-1 $\alpha$ and several AAA-related factors was observed in contractile SMCs in the initial stage after induction of hypoperfusion. In addition, the pathological features of hypoperfusion-induced AAA in this study were consistent with those of human AAA. This study suggested that hypoperfusion could induce AAA-related factors, as reported in human AAA studies. However, the limitations of this study should be noted. Because this study was observational, the 
interrelation between these factors was not determined. The time lag of the dynamic pattern of HIF- $1 \alpha$-related factors suggests the existence of an unidentified interactional cascade. Further studies are required to elucidate these points.

\section{Conclusions}

Time-dependent pathological analysis is important to understand the mechanism underlying AAA formation and development. We found that five groups were formed by dynamically changing the time. VV stenosis, as an inducer of increased HIF- $1 \alpha$ levels, may be a new drug development target. Our time-dependent pathological analysis clarified the black box of AAA pathology.

Supplementary Materials: The following are available online at https:/ /www.mdpi.com/2079-7 737/10/2/149/s1, Figure S1: Induction of abdominal aortic wall hypoperfusion; Figure S2: Immunohistochemical staining for synthetic vascular smooth muscle (SMemb), neutrophil elastase, angiotensinogen, angiotensin II type 1 (AT1) receptor, malondialdehyde (MDA) and endothelin-1 (ET-1); Figure S3: Time-dependent changes of the abdominal aortic aneurysm dilation; Figure S4: Time-dependent changes of matrix metalloproteinase (MMP) -2 and MMP-9 from day 0 to 28; Figure S5: Time-dependent changes of matrix metalloproteinase (MMP) - 12 and neutrophil elastase from day 0 to 28; Figure S6: Time-dependent changes of mac387+ and CD163+ macrophages from day 0 to 28; Figure S7: Time-dependent change of monocyte chemoattractant protein-1 (MCP-1) from day 0 to 28; Figure S8: Time-dependent changes of contractile vascular smooth muscle ( $\alpha$-smooth muscle actin ( $\alpha$-SMA)) and synthetic vascular smooth muscle (SMemb) from day 0 to 28; Figure S9: Time-dependent changes of angiotensinogen, and angiotensin II type 1 (AT1) receptor from day 0 to 28; Figure S10: Time-dependent changes of endothelin-1 (ET-1) and malondialdehyde (MDA) from day 0 to 28; Figure S11: Localization of angiotensin II type 1 (AT1) receptor, $\alpha$-smooth muscle actin $(\alpha$-SMA $)+$ cells and mac387+ macrophages in the aortic wall; Figure S12: Localization of endothelin-1 (ET-1), $\alpha$-smooth muscle actin $(\alpha$-SMA) + cells and mac387+ macrophages in the aortic wall; Figure S13: Localization of malondialdehyde (MDA), $\alpha$-smooth muscle actin $(\alpha$-SMA) + cells and mac387+ macrophages in the aortic wall; Figure S14: Localization of matrix metalloproteinase (MMP) -2, $\alpha$-smooth muscle actin ( $\alpha$-SMA) + cells and mac387+ macrophages in the aortic wall; Figure S15: Localization of matrix metalloproteinase (MMP) $-9, \alpha$-smooth muscle actin $(\alpha$-SMA) + cells and mac387+ macrophages in the aortic wall; Figure S16: Localization of matrix metalloproteinase (MMP) - $12, \alpha$-smooth muscle actin $(\alpha-\mathrm{SMA})+$ cells and mac387+ macrophages in the aortic wall; Figure S17: Localization of monocyte chemoattractant protein-1 (MCP-1), $\alpha$-smooth muscle actin $(\alpha-\mathrm{SMA})+$ cells and mac387+ macrophages in the aortic wall; Figure S18: Localization of neutrophil elastase, $\alpha$-smooth muscle actin $(\alpha-\mathrm{SMA})+$ cells and mac387+ macrophages in the aortic wall; Figure S19: Localization of angiotensinogen, $\alpha$-smooth muscle actin $(\alpha$-SMA) + cells and mac387+ macrophages in the aortic wall.

Author Contributions: Conceptualization, H.K. and N.Z.; Methodology, H.K. and N.Z.; Software, H.K. and W.S.; Validation, H.K. and W.S.; Formal analysis, H.K., W.S., R.F. and N.Z.; Investigation, H.K. and W.S.; Resources, H.K. and N.Z.; Data curation, H.K.; Writing—original draft preparation, H.K.; Writing—review and editing, H.T., T.M. and N.Z.; Visualization, H.K. and W.S.; Supervision, N.Z.; Project administration, N.Z.; Funding acquisition, H.K. and N.Z. All authors have read and agreed to the published version of the manuscript.

Funding: This work was supported by Grant-in-Aid for Scientific Research (B) (17H03822) (to N.Z.), 2020 Kindai University Research Enhancement Grant (KD2004) (to N.Z.) and Grant-in-Aid for JSPS Research Fellow (18J12856) (to H.K.) from the Japan Society for the Promotion of Science.

Institutional Review Board Statement: All animal experiments were approved by the Kindai University Animal Care and Use Committee and performed according to the Kindai University Animal Experimentation Regulations (approval number: KAAG-31-006).

Informed Consent Statement: Not applicable.

Data Availability Statement: Data of this study are available from the corresponding author.

Conflicts of Interest: The authors declare no conflict of interest. 


\section{References}

1. Weintraub, N.L. Understanding abdominal aortic aneurysm. N. Engl. J. Med. 2009, 361, 1114-1116. [CrossRef] [PubMed]

2. Moll, F.L.; Powell, J.T.; Fraedrich, G.; Verzini, F.; Haulon, S.; Waltham, M.; van Herwaarden, J.A.; Holt, P.J.; van Keulen, J.W.; Rantner, B.; et al. Management of abdominal aortic aneurysms clinical practice guidelines of the European society for vascular surgery. Eur. J. Vasc. Endovasc. Surg. 2011, 41 (Suppl. 1), S1-S58. [CrossRef]

3. Kuivaniemi, H.; Ryer, E.J.; Elmore, J.R.; Tromp, G. Understanding the pathogenesis of abdominal aortic aneurysms. Expert Rev. Cardiovasc. Ther. 2015, 13, 975-987. [CrossRef]

4. Wolinsky, H.; Glagov, S. Comparison of abdominal and thoracic aortic medial structure in mammals. Deviat. Man Usual Pattern Circ. Res. 1969, 25, 677-686. [CrossRef] [PubMed]

5. Blassova, T.; Tonar, Z.; Tomasek, P.; Hosek, P.; Hollan, I.; Treska, V.; Molacek, J. Inflammatory cell infiltrates, hypoxia, vascularization, pentraxin 3 and osteoprotegerin in abdominal aortic aneurysms-A quantitative histological study. PLoS ONE 2019, 14, e0224818. [CrossRef] [PubMed]

6. Vorp, D.A.; Lee, P.C.; Wang, D.H.; Makaroun, M.S.; Nemoto, E.M.; Ogawa, S.; Webster, M.W. Association of intraluminal thrombus in abdominal aortic aneurysm with local hypoxia and wall weakening. J. Vasc. Surg. 2001, 34, 291-299. [CrossRef] [PubMed]

7. Tanaka, H.; Zaima, N.; Sasaki, T.; Hayasaka, T.; Goto-Inoue, N.; Onoue, K.; Ikegami, K.; Morita, Y.; Yamamoto, N.; Mano, Y.; et al. Adventitial vasa vasorum arteriosclerosis in abdominal aortic aneurysm. PLoS ONE 2013, 8, e57398. [CrossRef] [PubMed]

8. Tanaka, H.; Zaima, N.; Sasaki, T.; Sano, M.; Yamamoto, N.; Saito, T.; Inuzuka, K.; Hayasaka, T.; Goto-Inoue, N.; Sugiura, Y.; et al. Hypoperfusion of the Adventitial Vasa Vasorum Develops an Abdominal Aortic Aneurysm. PLoS ONE 2015, 10, e0134386. [CrossRef]

9. Kugo, H.; Zaima, N.; Tanaka, H.; Mouri, Y.; Yanagimoto, K.; Hayamizu, K.; Hashimoto, K.; Sasaki, T.; Sano, M.; Yata, T.; et al. Adipocyte in vascular wall can induce the rupture of abdominal aortic aneurysm. Sci. Rep. 2016, 6, 31268. [CrossRef] [PubMed]

10. Sakalihasan, N.; Limet, R.; Defawe, O.D. Abdominal aortic aneurysm. Lancet 2005, 365, 1577-1589. [CrossRef]

11. Doderer, S.A.; Gabel, G.; Kokje, V.B.C.; Northoff, B.H.; Holdt, L.M.; Hamming, J.F.; Lindeman, J.H.N. Adventitial adipogenic degeneration is an unidentified contributor to aortic wall weakening in the abdominal aortic aneurysm. J. Vasc. Surg. 2017, 67, 1891-1900. [CrossRef]

12. Niestrawska, J.A.; Regitnig, P.; Viertler, C.; Cohnert, T.U.; Babu, A.R.; Holzapfel, G.A. The role of tissue remodeling in mechanics and pathogenesis of abdominal aortic aneurysms. Acta Biomater 2019, 88, 149-161. [CrossRef]

13. Tanaka, H.; Zaima, N.; Sasaki, T.; Yamamoto, N.; Inuzuka, K.; Sano, M.; Saito, T.; Hayasaka, T.; Goto-Inoue, N.; Sato, K.; et al. Imaging Mass Spectrometry Reveals a Unique Distribution of Triglycerides in the Abdominal Aortic Aneurysmal Wall. J. Vasc Res. 2015, 52, 127-135. [CrossRef] [PubMed]

14. Adolph, R.; Vorp, D.A.; Steed, D.L.; Webster, M.W.; Kameneva, M.V.; Watkins, S.C. Cellular content and permeability of intraluminal thrombus in abdominal aortic aneurysm. J. Vasc. Surg. 1997, 25, 916-926. [CrossRef]

15. Iijima, M.; Azuma, R.; Hieda, T.; Makino, Y. A surgical case of inflammatory abdominal aortic aneurysm that responded remarkably to preoperative steroid therapy. J. Surg. Case Rep. 2018, 2018, rjy020. [CrossRef]

16. Henderson, E.L.; Geng, Y.J.; Sukhova, G.K.; Whittemore, A.D.; Knox, J.; Libby, P. Death of smooth muscle cells and expression of mediators of apoptosis by T lymphocytes in human abdominal aortic aneurysms. Circulation 1999, 99, 96-104. [CrossRef]

17. Sakalihasan, N.; Delvenne, P.; Nusgens, B.V.; Limet, R.; Lapiere, C.M. Activated forms of MMP2 and MMP9 in abdominal aortic aneurysms. J. Vasc. Surg. 1996, 24, 127-133. [CrossRef]

18. Yamashita, A.; Noma, T.; Nakazawa, A.; Saito, S.; Fujioka, K.; Zempo, N.; Esato, K. Enhanced expression of matrix metalloproteinase-9 in abdominal aortic aneurysms. World J. Surg. 2001, 25, 259-265. [CrossRef]

19. Emeto, T.I.; Moxon, J.V.; Au, M.; Golledge, J. Oxidative stress and abdominal aortic aneurysm: Potential treatment targets. Clin. Sci. 2016, 130, 301-315. [CrossRef]

20. Guzik, B.; Sagan, A.; Ludew, D.; Mrowiecki, W.; Chwala, M.; Bujak-Gizycka, B.; Filip, G.; Grudzien, G.; Kapelak, B.; Zmudka, K.; et al. Mechanisms of oxidative stress in human aortic aneurysms-association with clinical risk factors for atherosclerosis and disease severity. Int. J. Cardiol. 2013, 168, 2389-2396. [CrossRef] [PubMed]

21. Kugo, H.; Zaima, N.; Tanaka, H.; Hashimoto, K.; Miyamoto, C.; Sawaragi, A.; Urano, T.; Unno, N.; Moriyama, T. Pathological Analysis of the Ruptured Vascular Wall of Hypoperfusion-induced Abdominal Aortic Aneurysm Animal Model. J. Oleo Sci. 2017, 66, 499-506. [CrossRef]

22. Gabel, G.; Northoff, B.H.; Weinzierl, I.; Ludwig, S.; Hinterseher, I.; Wilfert, W.; Teupser, D.; Doderer, S.A.; Bergert, H.; Schonleben, F.; et al. Molecular Fingerprint for Terminal Abdominal Aortic Aneurysm Disease. J. Am. Heart Assoc. 2017, 6, e006798. [CrossRef]

23. Curci, J.A.; Liao, S.; Huffman, M.D.; Shapiro, S.D.; Thompson, R.W. Expression and localization of macrophage elastase (matrix metalloproteinase-12) in abdominal aortic aneurysms. J. Clin. Invest. 1998, 102, 1900-1910. [CrossRef]

24. Dale, M.A.; Ruhlman, M.K.; Baxter, B.T. Inflammatory cell phenotypes in AAAs: Their role and potential as targets for therapy. Arterioscler. Thromb. Vasc. Biol. 2015, 35, 1746-1755. [CrossRef]

25. Rubio-Navarro, A.; Amaro Villalobos, J.M.; Lindholt, J.S.; Buendia, I.; Egido, J.; Blanco-Colio, L.M.; Samaniego, R.; Meilhac, O.; Michel, J.B.; Martin-Ventura, J.L.; et al. Hemoglobin induces monocyte recruitment and CD163-macrophage polarization in abdominal aortic aneurysm. Int. J. Cardiol. 2015, 201, 66-78. [CrossRef] [PubMed] 
26. Koch, A.E.; Kunkel, S.L.; Pearce, W.H.; Shah, M.R.; Parikh, D.; Evanoff, H.L.; Haines, G.K.; Burdick, M.D.; Strieter, R.M. Enhanced production of the chemotactic cytokines interleukin- 8 and monocyte chemoattractant protein-1 in human abdominal aortic aneurysms. Am. J. Pathol. 1993, 142, 1423-1431.

27. Zhong, L.; He, X.; Si, X.; Wang, H.; Li, B.; Hu, Y.; Li, M.; Chen, X.; Liao, W.; Liao, Y.; et al. SM22alpha (Smooth Muscle 22alpha) Prevents Aortic Aneurysm Formation by Inhibiting Smooth Muscle Cell Phenotypic Switching Through Suppressing Reactive Oxygen Species/NF-kappaB (Nuclear Factor-kappaB). Arterioscler. Thromb. Vasc. Biol. 2019, 39, e10-e25. [CrossRef] [PubMed]

28. Miyamoto, C.; Kugo, H.; Hashimoto, K.; Moriyama, T.; Zaima, N. Ovariectomy increases the incidence and diameter of abdominal aortic aneurysm in a hypoperfusion-induced abdominal aortic aneurysm animal model. Sci. Rep. 2019, 9, 18330. [CrossRef] [PubMed]

29. Kanda, Y. Investigation of the freely available easy-to-use software 'EZR' for medical statistics. Bone Marrow Transplant. 2013, 48, 452-458. [CrossRef] [PubMed]

30. Kugo, H.; Moriyama, T.; Zaima, N. The role of perivascular adipose tissue in the appearance of ectopic adipocytes in the abdominal aortic aneurysmal wall. Adipocyte 2019, 8, 229-239. [CrossRef] [PubMed]

31. Kugo, H.; Zaima, N.; Mouri, Y.; Tanaka, H.; Yanagimoto, K.; Urano, T.; Unno, N.; Moriyama, T. The preventive effect of fish oil on abdominal aortic aneurysm development. Biosci. Biotechnol. Biochem. 2016, 80, 1186-1191. [CrossRef] [PubMed]

32. Sano, M.; Sasaki, T.; Hirakawa, S.; Sakabe, J.; Ogawa, M.; Baba, S.; Zaima, N.; Tanaka, H.; Inuzuka, K.; Yamamoto, N.; et al. Lymphangiogenesis and angiogenesis in abdominal aortic aneurysm. PLoS ONE 2014, 9, e89830. [CrossRef] [PubMed]

33. Thompson, R.W. Basic science of abdominal aortic aneurysms: Emerging therapeutic strategies for an unresolved clinical problem. Curr. Opin. Cardiol. 1996, 11, 504-518. [CrossRef] [PubMed]

34. Matsushita, M.; Nishikimi, N.; Sakurai, T.; Nimura, Y. Relationship between aortic calcification and atherosclerotic disease in patients with abdominal aortic aneurysm. Int. Angiol. 2000, 19, 276-279.

35. Lindholt, J.S. Aneurysmal wall calcification predicts natural history of small abdominal aortic aneurysms. Atherosclerosis 2008, 197, 673-678. [CrossRef] [PubMed]

36. Nakayama, A.; Morita, H.; Hayashi, N.; Nomura, Y.; Hoshina, K.; Shigematsu, K.; Ohtsu, H.; Miyata, T.; Komuro, I. Inverse Correlation Between Calcium Accumulation and the Expansion Rate of Abdominal Aortic Aneurysms. Circ. J. 2016, 80, 332-339. [CrossRef]

37. Thompson, R.W.; Parks, W.C. Role of matrix metalloproteinases in abdominal aortic aneurysms. Ann. N. Y. Acad. Sci. 1996, 800, 157-174. [CrossRef]

38. Hashimoto, K.; Kugo, H.; Tanaka, H.; Iwamoto, K.; Miyamoto, C.; Urano, T.; Unno, N.; Hayamizu, K.; Zaima, N.; Moriyama, T. The Effect of a High-Fat Diet on the Development of Abdominal Aortic Aneurysm in a Vascular Hypoperfusion-Induced Animal Model. J. Vasc. Res. 2018, 55, 63-74. [CrossRef]

39. Miyamoto, C.; Kugo, H.; Hashimoto, K.; Sawaragi, A.; Zaima, N.; Moriyama, T. Effect of a High-sucrose Diet on Abdominal Aortic Aneurysm Development in a Hypoperfusion-induced Animal Model. J. Oleo. Sci. 2018, 67, 589-597. [CrossRef]

40. Ghigliotti, G.; Barisione, C.; Garibaldi, S.; Brunelli, C.; Palmieri, D.; Spinella, G.; Pane, B.; Spallarossa, P.; Altieri, P.; Fabbi, P.; et al. CD16(+) monocyte subsets are increased in large abdominal aortic aneurysms and are differentially related with circulating and cell-associated biochemical and inflammatory biomarkers. Dis. Markers 2013, 34, 131-142. [CrossRef]

41. Kamijima, T.; Isobe, M.; Suzuki, J.; Fukui, D.; Arai, M.; Urayama, H.; Nishimaki, K.; Sekiguchi, M.; Kawasaki, S. Enhanced embryonic nonmuscle myosin heavy chain isoform and matrix metalloproteinase expression in aortic abdominal aneurysm with rapid progression. Cardiovasc. Pathol. 1999, 8, 291-295. [CrossRef]

42. Cohen, J.R.; Parikh, S.; Grella, L.; Sarfati, I.; Corbie, G.; Danna, D.; Wise, L. Role of the neutrophil in abdominal aortic aneurysm development. Cardiovasc Surg. 1993, 1, 373-376. [PubMed]

43. Kaschina, E.; Scholz, H.; Steckelings, U.M.; Sommerfeld, M.; Kemnitz, U.R.; Artuc, M.; Schmidt, S.; Unger, T. Transition from atherosclerosis to aortic aneurysm in humans coincides with an increased expression of RAS components. Atherosclerosis 2009, 205, 396-403. [CrossRef] [PubMed]

44. Miller, F.J., Jr.; Sharp, W.J.; Fang, X.; Oberley, L.W.; Oberley, T.D.; Weintraub, N.L. Oxidative stress in human abdominal aortic aneurysms: A potential mediator of aneurysmal remodeling. Arterioscler. Thromb Vasc. Biol. 2002, 22, 560-565. [CrossRef] [PubMed]

45. Cassis, L.A.; Rateri, D.L.; Lu, H.; Daugherty, A. Bone marrow transplantation reveals that recipient AT1a receptors are required to initiate angiotensin II-induced atherosclerosis and aneurysms. Arterioscler. Thromb Vasc. Biol. 2007, 27, 380-386. [CrossRef] [PubMed]

46. Chen, X.L.; Tummala, P.E.; Olbrych, M.T.; Alexander, R.W.; Medford, R.M. Angiotensin II induces monocyte chemoattractant protein-1 gene expression in rat vascular smooth muscle cells. Circ. Res. 1998, 83, 952-959. [CrossRef]

47. Griendling, K.K.; Minieri, C.A.; Ollerenshaw, J.D.; Alexander, R.W. Angiotensin II stimulates NADH and NADPH oxidase activity in cultured vascular smooth muscle cells. Circ. Res. 1994, 74, 1141-1148. [CrossRef]

48. Wang, C.; Qian, X.; Sun, X.; Chang, Q. Angiotensin II increases matrix metalloproteinase 2 expression in human aortic smooth muscle cells via AT1R and ERK1/2. Exp. Biol. Med. 2015, 240, 1564-1571. [CrossRef] [PubMed]

49. Li, M.W.; Mian, M.O.; Barhoumi, T.; Rehman, A.; Mann, K.; Paradis, P.; Schiffrin, E.L. Endothelin-1 overexpression exacerbates atherosclerosis and induces aortic aneurysms in apolipoprotein E knockout mice. Arterioscler. Thromb Vasc. Biol. 2013, 33, 2306-2315. [CrossRef] 
50. Flondell-Site, D.; Lindblad, B.; Gottsater, A. High levels of endothelin (ET)-1 and aneurysm diameter independently predict growth of stable abdominal aortic aneurysms. Angiology 2010, 61, 324-328. [CrossRef]

51. Treska, V.; Wenham, P.W.; Valenta, J.; Topolcan, O.; Pecen, L. Plasma endothelin levels in patients with abdominal aortic aneurysms. Eur. J. Vasc. Endovasc. Surg. 1999, 17, 424-428. [CrossRef] [PubMed]

52. Lucas, M.L.; Carraro, C.C.; Bello-Klein, A.; Kalil, A.N.; Aerts, N.R.; Carvalho, F.B.; Fernandes, M.C.; Zettler, C.G. Oxidative Stress in Aortas of Patients with Advanced Occlusive and Aneurysmal Diseases. Ann. Vasc. Surg. 2018, 52, 216-224. [CrossRef]

53. Siasos, G.; Mourouzis, K.; Oikonomou, E.; Tsalamandris, S.; Tsigkou, V.; Vlasis, K.; Vavuranakis, M.; Zografos, T.; Dimitropoulos, S.; Papaioannou, T.G.; et al. The Role of Endothelial Dysfunction in Aortic Aneurysms. Curr. Pharm. Des. 2015, 21, $4016-4034$. [CrossRef] [PubMed]

54. Manalo, D.J.; Rowan, A.; Lavoie, T.; Natarajan, L.; Kelly, B.D.; Ye, S.Q.; Garcia, J.G.; Semenza, G.L. Transcriptional regulation of vascular endothelial cell responses to hypoxia by HIF-1. Blood 2005, 105, 659-669. [CrossRef]

55. Erdozain, O.J.; Pegrum, S.; Winrow, V.R.; Horrocks, M.; Stevens, C.R. Hypoxia in abdominal aortic aneurysm supports a role for HIF-1alpha and Ets-1 as drivers of matrix metalloproteinase upregulation in human aortic smooth muscle cells. J. Vasc Res. 2011, 48, 163-170. [CrossRef] [PubMed]

56. Wang, S.; Zhang, C.; Zhang, M.; Liang, B.; Zhu, H.; Lee, J.; Viollet, B.; Xia, L.; Zhang, Y.; Zou, M.H. Activation of AMP-activated protein kinase alpha2 by nicotine instigates formation of abdominal aortic aneurysms in mice in vivo. Nat. Med. 2012, 18, 902-910. [CrossRef]

57. Wan, R.; Mo, Y.; Chien, S.; Li, Y.; Tollerud, D.J.; Zhang, Q. The role of hypoxia inducible factor-1alpha in the increased MMP-2 and MMP-9 production by human monocytes exposed to nickel nanoparticles. Nanotoxicology 2011, 5, 568-582. [CrossRef]

58. Aikawa, M.; Sivam, P.N.; Kuro-o, M.; Kimura, K.; Nakahara, K.; Takewaki, S.; Ueda, M.; Yamaguchi, H.; Yazaki, Y.; Periasamy, M.; et al. Human smooth muscle myosin heavy chain isoforms as molecular markers for vascular development and atherosclerosis. Circ. Res. 1993, 73, 1000-1012. [CrossRef] [PubMed]

59. Owens, G.K. Regulation of differentiation of vascular smooth muscle cells. Physiol. Rev. 1995, 75, 487-517. [CrossRef]

60. Salmon, M.; Johnston, W.F.; Woo, A.; Pope, N.H.; Su, G.; Upchurch, G.R., Jr.; Owens, G.K.; Ailawadi, G. KLF4 regulates abdominal aortic aneurysm morphology and deletion attenuates aneurysm formation. Circulation 2013, 128, S163-S174. [CrossRef] [PubMed]

61. Ailawadi, G.; Moehle, C.W.; Pei, H.; Walton, S.P.; Yang, Z.; Kron, I.L.; Lau, C.L.; Owens, G.K. Smooth muscle phenotypic modulation is an early event in aortic aneurysms. J. Thorac. Cardiovasc. Surg. 2009, 138, 1392-1399. [CrossRef] [PubMed]

62. Takahashi, K.; Yamanaka, S. Induction of pluripotent stem cells from mouse embryonic and adult fibroblast cultures by defined factors. Cell 2006, 126, 663-676. [CrossRef] [PubMed]

63. Mathieu, J.; Zhang, Z.; Zhou, W.; Wang, A.J.; Heddleston, J.M.; Pinna, C.M.; Hubaud, A.; Stadler, B.; Choi, M.; Bar, M.; et al. HIF induces human embryonic stem cell markers in cancer cells. Cancer Res. 2011, 71, 4640-4652. [CrossRef]

64. Spinosa, M.; Su, G.; Salmon, M.D.; Lu, G.; Cullen, J.M.; Fashandi, A.Z.; Hawkins, R.B.; Montgomery, W.; Meher, A.K.; Conte, M.S.; et al. Resolvin D1 decreases abdominal aortic aneurysm formation by inhibiting NETosis in a mouse model. J. Vasc. Surg. 2018, 68, 93S-103S. [CrossRef] [PubMed]

65. Pagano, M.B.; Bartoli, M.A.; Ennis, T.L.; Mao, D.; Simmons, P.M.; Thompson, R.W.; Pham, C.T. Critical role of dipeptidyl peptidase I in neutrophil recruitment during the development of experimental abdominal aortic aneurysms. Proc. Natl. Acad. Sci. USA 2007, 104, 2855-2860. [CrossRef]

66. Papayannopoulos, V.; Metzler, K.D.; Hakkim, A.; Zychlinsky, A. Neutrophil elastase and myeloperoxidase regulate the formation of neutrophil extracellular traps. J. Cell Biol. 2010, 191, 677-691. [CrossRef] [PubMed]

67. Yan, H.; Zhou, H.F.; Akk, A.; Hu, Y.; Springer, L.E.; Ennis, T.L.; Pham, C.T.N. Neutrophil Proteases Promote Experimental Abdominal Aortic Aneurysm via Extracellular Trap Release and Plasmacytoid Dendritic Cell Activation. Arterioscler. Thromb Vasc. Biol. 2016, 36, 1660-1669. [CrossRef]

68. Evans, C.E. Hypoxia and HIF activation as a possible link between sepsis and thrombosis. Thromb J. 2019, 17, 16. [CrossRef] [PubMed]

69. Kobori, H.; Harrison-Bernard, L.M.; Navar, L.G. Expression of angiotensinogen mRNA and protein in angiotensin II-dependent hypertension. J. Am. Soc. Nephrol. 2001, 12, 431-439. [PubMed]

70. Abdul-Hafez, A.; Shu, R.; Uhal, B.D. JunD and HIF-1alpha mediate transcriptional activation of angiotensinogen by TGF-beta1 in human lung fibroblasts. FASEB J. 2009, 23, 1655-1662. [CrossRef]

71. Koh, T.J.; DiPietro, L.A. Inflammation and wound healing: The role of the macrophage. Expert Rev. Mol. Med. 2011, 13, e23. [CrossRef] [PubMed]

72. Szade, A.; Grochot-Przeczek, A.; Florczyk, U.; Jozkowicz, A.; Dulak, J. Cellular and molecular mechanisms of inflammationinduced angiogenesis. IUBMB Life 2015, 67, 145-159. [CrossRef] [PubMed]

73. Weis, N.; Weigert, A.; von Knethen, A.; Brune, B. Heme oxygenase-1 contributes to an alternative macrophage activation profile induced by apoptotic cell supernatants. Mol. Biol. Cell 2009, 20, 1280-1288. [CrossRef] [PubMed]

74. Sierra-Filardi, E.; Vega, M.A.; Sanchez-Mateos, P.; Corbi, A.L.; Puig-Kroger, A. Heme Oxygenase-1 expression in M-CSF-polarized M2 macrophages contributes to LPS-induced IL-10 release. Immunobiology 2010, 215, 788-795. [CrossRef] [PubMed] 